\title{
Вдосконалення технічної підготовленості спортсменок художньої гімнастики засобами народно-сценічного танцю
}

\section{Петро Кизім ${ }^{1}$ \\ Наталія Батєєва ${ }^{2}$}

Харківська державна академія фізичної культури ${ }^{1}$ Харків, Україна,

Київський національний університет культури і мистецтв², Київ, Україна

Мета: експериментально обгрунтувати вдосконалення технічної підготовленості спортсменок художньої гімнастики віку 10-12 років засобами народно-сценічного танцю.

Матеріал і методи: теоретичний аналіз і узагальнення даних спеціальної науково-методичної літератури, педагогічне спостереження, педагогічне тестування, педагогічний експеримент, метод експертних оцінок, методи математичної статистики. У дослідженні бралии участь 14 гімнасток у віці 10-12 років. Поділено на дві групи: контрольну групу (КГ) 7 гімнасток та основну групу(ОГ) 7 гімнасток.

Результати: виявлено, що рівень технічної підготовленості більш відчутно зріс у гімнасток основної групи, де в навчально-тренувальному процесі застосовано засоби народно-сценічного танцю.

Висновки: встановлено позитивний вплив засобів народно-сценічного танцю на динаміку рівня технічної підготовленості спортсменок художньої гімнастики. Підтвердженням ефективності розробленої методики було статистично зміни у гімнасток основної групи. У гімнасток контрольної групи спостерігалася позитивна динаміка результатів, але статистично значущих змін не спостерігалося.

Ключові слова: художня гімнастика, спортсменки, технічна підготовленість, народно-сценічний танець.

\section{Вступ}

Виконання змагальних програм у сучасній художній гімнастиці потребує від гімнасток високої технічної майстерності. Традиційні засоби технічної підготовки у навчально-тренувальному процесі гімнасток не в повній мірі відповідають сучасному динамізму і еволюції структури змагальних програм і їх виконання [14, 15]. Вдосконалення техніки виконання труднощів тіла (стрибки, повороти, рівноваги) і виразності їх виконання потребує від гімнасток всебічної хореографічної підготовленості, оскільки одним із способів підвищити вартість композиції змагання можливо за рахунок виконання складних і «дорогих» елементів труднощів тіла [8, 12, 13].

Підвищення виконавської майстерності гімнасток на основі вдосконалення хореографічної підготовки розглянуті в дослідженнях Гевара Перез Хорхе Енріке (1994) і С.I. Борісенко (2000). Дослідження С.І. Борісенко (2000), пов'язані з підвищенням виконавської майстерності гімнасток на основі вдосконалення хореографічної підготовки. Вона показала, що пріоритет вітчизняної гімнастики обумовлений не лише високою спортивнотехнічною майстерністю, але і особливою естетичністю, яка відбивається у виступах.

Ряд науковців (І.А. Вінер, 2003; Л.А. Карпенко, 2007; P.I. Андрєєва, 2011) звертають увагу на те, що специфіка підготовки в художній гімнастиці визначається тим, що мета вправ полягає в досягненні гармонії рухів. Високі результати визначають абсолютними величинами одно- го з компонентів: швидкості, гнучкості, сили, витривалості, координації, а також особливими зв'язками між різними сторонами рухових проявів.

Аналіз спеціальної науково-методичної літератури показав, що застосування сучасних напрямків хореографії в підготовці юних спортсменок має місце, але застосування рухів народно-сценічного танцю здебільшого не просліджується. Вирішення проблематики даної теми є своєчасною так, як розвиток художньої гімнастики проходить на теренах всієї України. Кожен регіон нашої країни має свій колорит, фольклорність, що може дати невичерпне багаття рухів як фольклорного так і народно-сценічного танцю [5, 10, 17]. При сполученні хореографічних рухів з майстерністю виконання вправ з предметами спортсменки художньої гімнастики відтворюють неповторну палітру красок жіночої пластики, її перевтілення в різні образи згідно музичного супроводу і його драматургії $[11,16]$.

Характерні риси рухів народно-сценічного танцю дають граціозність та динамізм у їх виконанні. Сплетіння багатогранного змісту народно-сценічного танцю з хореографічним рисунком, емоційною складовою музичного твору відображає його народність та епоху. Народно-сценічний танець характеризується від спокійних хороводних образних народних замальовок до швидкого руху в хореографічному рисунку з виконанням в ньому складних по техніці вправ того чи іншого епізоду в темі відтворення епохи або сьогодення [7]. Вище викладене свідчить про 


\section{СЛОБОЖАНСЬКИЙ НАУКОВО-СПОРТИВНИЙ ВІСНИК}

неймовірно багатий, невичерпний колорит народно-сценічного танцю, який за своїми якостями притаманний для застосування у структуру та виконання змагальної програми у виді спорту - художня гімнастика. Зважаючи на це наше дослідження, що до впливу народно-сценічного танцю на рівень технічної підготовленості спортсменок 3 художньої гімнастики, є актуальним.

Зв'язок дослідження з науковими програмами, планами, темами. Дослідження виконано відповідно до ініціативної теми наукового дослідження кафедри гімнастики, танцювальних видів спорту та хореографії ХДАФК: «Теоретико-методологічні основи розвитку системоутворюючих компонентів фізичної культури (спорт, фітнес і рекреація) на 2020-2025 рр., номер державної реєстрації 0120001215

Мета дослідження: експериментально обґрунтувати вдосконалення технічної підготовленості спортсменок художньої гімнастики віку 10-12 років засобами народно-сценічного танцю.

\section{Матеріал і методи дослідження}

Теоретичний аналіз і узагальнення даних спеціальної науково-методичної літератури, педагогічне спостереження, педагогічне тестування, педагогічний експеримент, метод експертних оцінок, методи математично статистики. У дослідженні брали участь 7 гімнасток віку 10-12 років контрольної групи (КГ) і 7 гімнасток віку 1012 років основної групи (ОГ).

\section{Результати дослідження}

На початковому етапі дослідження визначені оцінювальні бали компонентів за критеріями при виконанні змагальної програми в контрольній групі (КГ) та основній групі (ОГ) Рис.1. та Рис.2.

Аналіз експертних оцінок виконання змагальної програми спортсменками даного віку на початку дослідження в контрольній групі дає привід констатувати велике роз- сіювання індивідуальних результатів та найбільшу різницю рівня технічної підготовленості спортсменок в компоненті складність елементів між кращим і гіршим їх виконанням, яка становить 1,0 бал від 7,4 балів до 8,4 балів ( $\mathrm{V}$ - 4,6\%). Ведучі фахівці художньої гімнастики свідчать, що в цьому віці різниця рівня технічної підготовленості спортсменок художньої гімнастики щодо техніки виконання в змагальних програмах компонента складність елементів має найбільшу різницю рівня технічної підготовленості, ніж у виконанні інших компонентів, що підтверджується експертними оцінками тестування в нашому дослідженні. Щодо інших результатів тестування, то в компонентах різноманітність рухів тіла від 7,5 балів до 7,8 балів (V - 1,3\%), оригінальність елементів і з'єднань від 7,4 балів до 7,8 балів (V - 3,1\%), техніка виконання елементів від 7,5 балів до 8,3 балів ( $\mathrm{V}-3,0)$, музичність виконання від 7,6 балів до 7,9 балів ( $\mathrm{V}-1,2 \%)$, амплітуда рухів від 7,4 балів до 7,8 балів (V - 2,1\%), переміщення по майданчику від 7,2 балів до 7,8 балів (V - 3,1\%) маємо мінімальні відмінності в розсіюванні індивідуальних результатів, які становлять різницю в межах від 0,6 до 0,3 балів. Очевидна однорідність групи, де коефіцієнт варіації V\% не перевищує значення 10 відсотків [9].

Проведено первинне тестування рівня технічної підготовленості гімнасток основної групи (ОГ) (Рис. 2.)

Проведене тестування в основній групі на початку експерименту показало, як і в контрольній групі, велике розсіювання результатів зафіксовано в компоненті складність елементів та найбільшу різницю рівня технічної підготовленості спортсменок між кращим і гіршим їх виконанням, яка становить 0,9 балів від 7,6 балів до 8,5 балів (V - 3,9\%).

Різниця результатів тестування по іншим компонентам не перевищує меж від 0,6 до 0,3 балів: різноманітність рухів тіла від 7,3 балів до 7,8 балів ( $V-2,1 \%$ ), оригінальність елементів і з'єднань від 7,3 балів до 7,9 балів ( $V$ - 2,6\%), техніка виконання елементів від 7,5 балів до $8,0$ балів ( $\mathrm{V}-2,0 \%)$, музичність виконання від 7,3 балів до 7,8 балів (V - 2,5\%), амплітудність рухів від 7,5 балів

\section{Г I М АСТКИ}
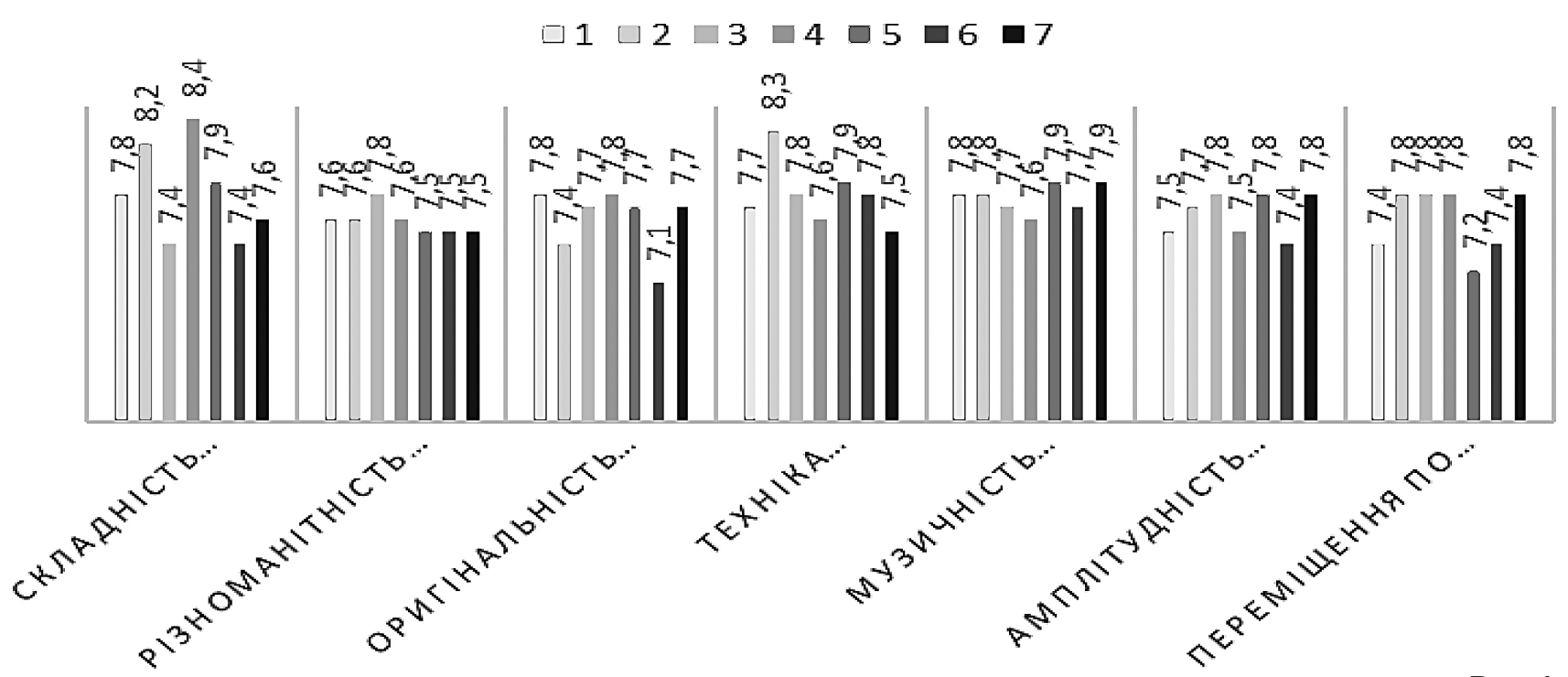

Рис.1.

Результати тестування технічної підготовленості гімнасток на первинному етапі експерименту (KГ, $\mathrm{n}=7)$ 
ГI М Н АСТИ
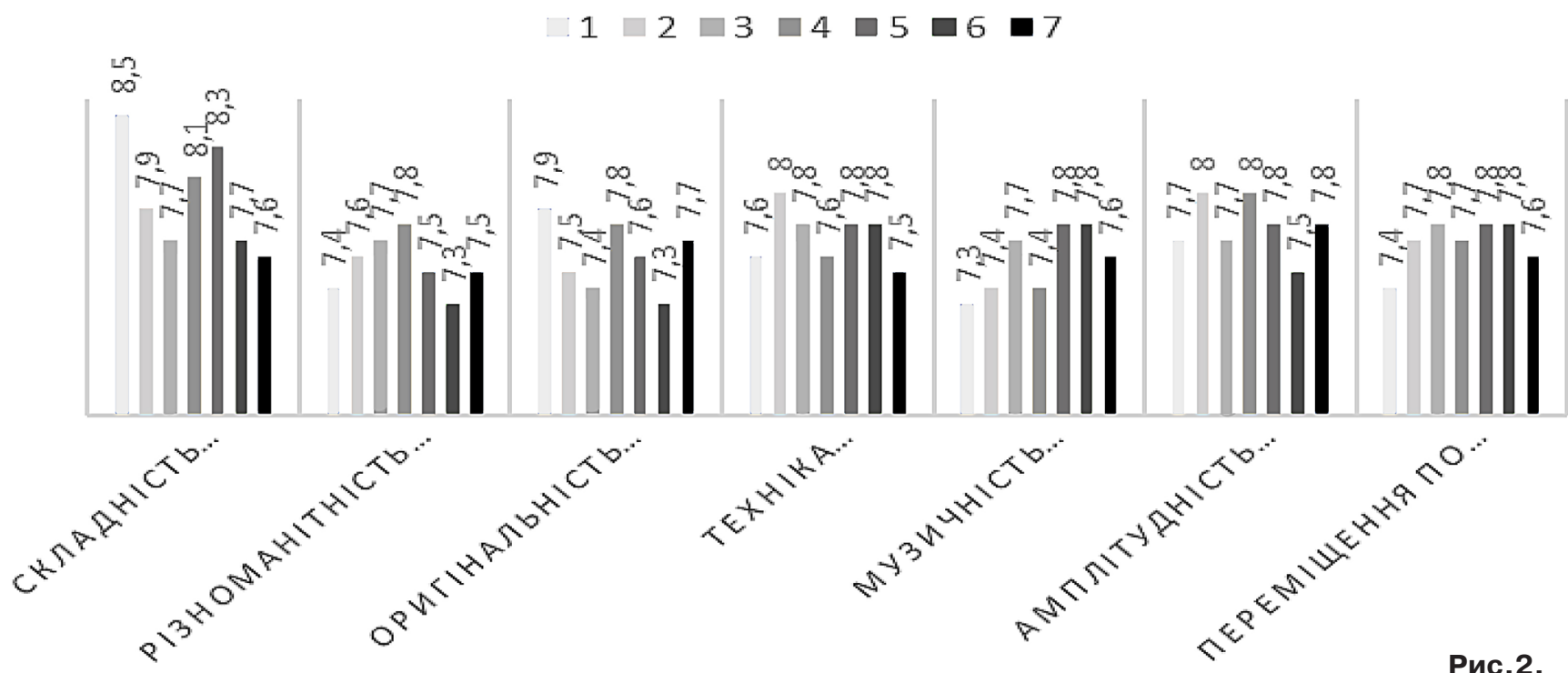

Рис.2.

Результати тестування технічної підготовленості гімнасток на первинному етапі експерименту (ОГ, $n=7)$

до 7,8 балів (V - 2,0\%), переміщення по майданчику від 7,4 балів до 7,8 балів (V - 1,8\%).

На підставі проведеного педагогічного дослідження нами була розроблена методика вдосконалення технічної підготовленості спортсменок з художньої гімнастики віком 10-12 років засобами народно-сценічного танцю. До неї були включені вправи виконання різновидів українського народно-сценічного танцю: характерні партерні та в безопорному русі оберти, доріжки.

Методику удосконалення технічної підготовленості спортсменів художньої гімнастики віком 10-12 років ми застосували в основній групі (ОГ, n=7). Навчально-тре- нувальний процес в контрольній групі (КГ, n=7) проходив за традиційною методикою підготовки спортсменок 3 художньої гімнастики. Вправи народно-сценічного танцю використовувались в основній групі у підготовчій та заключній частині тренувального заняття. Статистичні результати тестування в кінці педагогічного експерименту розміщені в таблицях $1,2$.

Показники оцінки компонентів виконання змагальної програми до та після педагогічного дослідження в ОГ показали динаміку змін: компонент «Складність елементів» в групі у відсотковому співвідношенні виріс на 7,8 \% (tp $=2,87, p<0,05)$; компонент «Різноманітність рухів тіла»

Таблиця 1

Статистичні показники технічної підготовленості гімнасток основної групи педагогічного експерименту $(\mathrm{n}=7, \mathrm{P}<0,05 ; 0,01 ; 0,001)$

\begin{tabular}{|c|c|c|c|c|c|}
\hline \multirow{3}{*}{$\begin{array}{l}\text { № } \\
3 / \Pi\end{array}$} & \multirow{3}{*}{ Компоненти } & \multicolumn{2}{|c|}{$\begin{array}{c}\text { Основна група } \\
(\mathrm{n}=7)\end{array}$} & \multirow{3}{*}{ tp } & \multirow{3}{*}{$\mathrm{p}$} \\
\hline & & на початку & після & & \\
\hline & & \multicolumn{2}{|c|}{$\bar{X} \pm \mathrm{m}$} & & \\
\hline 1 & Складність елементів, бали & $7,99 \pm 0,12$ & $8,61 \pm 0,18$ & 2,87 & $<0,05$ \\
\hline 2 & Різноманітність рухів тіла, бали & $7,61 \pm 0,06$ & $8,65 \pm 0,07$ & 11,28 & $<0,001$ \\
\hline 3 & $\begin{array}{l}\text { Оригінальність елементів і } \\
\text { 3’єднань, бали }\end{array}$ & $7,66 \pm 0,08$ & $8,31 \pm 0,06$ & 6,50 & $<0,001$ \\
\hline 4 & Техніка виконання елементів, бали & $7,67 \pm 0,06$ & $8,46 \pm 0,07$ & 8,57 & $<0,001$ \\
\hline 5 & Музичність виконання, бали & $7,64 \pm 0,08$ & $8,4 \pm 0,08$ & 6,72 & $<0,001$ \\
\hline 6 & Амплітудність рухів, бали & $7,82 \pm 0,06$ & $8,24 \pm 0,05$ & 5,38 & $<0,01$ \\
\hline 7 & Переміщення по майданчику, бали & $7,73 \pm 0,05$ & $8,38 \pm 0,06$ & 8,32 & $<0,001$ \\
\hline
\end{tabular}




\section{СЛОБОЖАНСЬКИЙ НАУКОВО-СПОРТИВНИЙ ВІСНИК}

Таблиця 2

Статистичні показники технічної підготовленості гімнасток контрольної групи педагогічного експерименту $(\mathrm{n}=7, \mathrm{P}<0,05)$

\begin{tabular}{|c|c|c|c|c|c|}
\hline \multirow{3}{*}{$\begin{array}{l}\text { № } \\
\text { 3/ח }\end{array}$} & \multirow{3}{*}{ Компоненти } & Контрольна & $\mathrm{Ia}(\mathrm{n}=7)$ & \multirow{3}{*}{ tp } & \multirow{3}{*}{$\mathrm{p}$} \\
\hline & & на початку & після & & \\
\hline & & \multicolumn{2}{|c|}{$\bar{X} \pm \mathrm{m}$} & & \\
\hline 1 & Складність елементів, бали & $7,81 \pm 0,15$ & $7,97 \pm 0,13$ & 0,81 & $>0,05$ \\
\hline 2 & Різноманітність рухів тіла, бали & $7,59 \pm 0,04$ & $7,68 \pm 0,06$ & 1,25 & $>0,05$ \\
\hline 3 & $\begin{array}{l}\text { Оригінальність елементів і } \\
\text { 3'єднань, бали }\end{array}$ & $7,60 \pm 0,10$ & $7,84 \pm 0,07$ & 1,97 & $>0,05$ \\
\hline 4 & $\begin{array}{l}\text { Техніка виконання елементів, } \\
\text { бали }\end{array}$ & $7,80 \pm 0,10$ & $8,01 \pm 0,09$ & 1,56 & $>0,05$ \\
\hline 5 & Музичність виконання, бали & $7,77 \pm 0,04$ & $7,9 \pm 0,05$ & 2,03 & $>0,05$ \\
\hline 6 & Амплітудність рухів, бали & $7,64 \pm 0,06$ & $7,77 \pm 0,07$ & 1,41 & $>0,05$ \\
\hline 7 & $\begin{array}{l}\text { Переміщення по майданчику, } \\
\text { бали }\end{array}$ & $7,60 \pm 0,10$ & $7,82 \pm 0,07$ & 1,80 & $>0,05$ \\
\hline
\end{tabular}

- на 13,6 \% (tp = 11,28, p < 0,001); компонент «Оригінальність елементів і з'єднань» - на 8,5\% (tp = 6,50, p < 0,001); компонент «Техніка виконання елементів» - на 10,3 \% (tp $=8,57, \mathrm{p}<0,001) ;$ компонент «Музичність виконання»на 9,9\% (tp $=6,72, p<0,01)$; компонент «Амплітудність рухів» - на $5,4 \%$ (tp $=5,38, \mathrm{p}<0,01)$; компонент «Переміщення по майданчику» - на 8,4 \% (tp $=8,32, p<0,001)$.

У той же час динаміка змін оцінки компонентів виконання змагальної програми на початку та після педагогічного дослідження в контрольній групі висвітлена в результатах: експертна оцінка компоненту «Складність елементів» в групі у відсотковому співвідношенні виросла на 1,3\% (tp = 0,46, p>0,05); компоненту «Різноманітність рухів тіла» - на 1,2\% (tp = 0,71, p>0,05); компоненту «Оригінальність елементів і з'єднань» - на 1,1% (tp
$=0,77, p>0,05)$; компоненту «Техніка виконання елементів» - на 2,5 \% (tp = 1,28, p>0,05); компоненту «Музичність виконання» - на $1,2 \%$ (tp $=0,54, \mathrm{p}>0,05)$; компоненту «Амплітудність рухів» - на 1,2 \% (tp = 0,57, p>0,05); компоненту «Переміщення по майданчику» - на 1,2 \% (tp $=0,44, p>0,05)$.

При проведенні порівняння показників рівня технічної підготовленості гімнасток основної та контрольної груп спостерігається достовірність результатів у всіх оцінних компонентах змагальної програми (Рис.3.)

У порівняльній характеристиці середньостатистичної оцінки компонентів виконання змагальної програми спортсменками художньої гімнастики встановлено позитивну різницю на користь основної групи. Відсоткове співвідношення становить: ОГ - 5,2\%; КГ - 1,4\%.

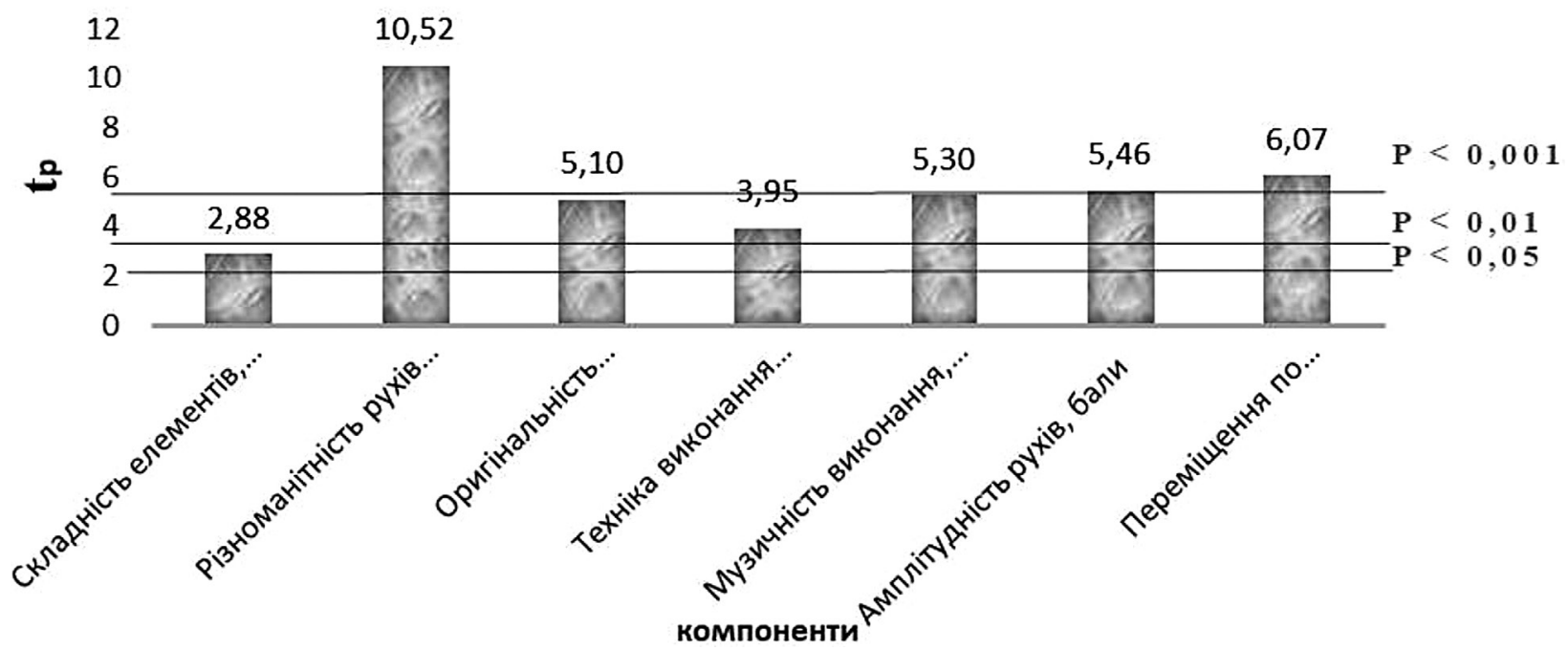

Рис.3.

Достовірність показників рівня технічної підготовленості гімнасток основної та контрольної групи після педагогічного експерименту 


\section{Висновки / Дискусія}

Дослідження з даної теми показало невичерпність наукових доробок та практичних підходів до впровадження в навчально-тренувальний процес нових інновацій та засобів народно-сценічного танцю у вдосконаленні технічної підготовленості спортсменок художньої гімнастики. Народно-сценічний танець у своєму багатогранному неповторному перевтіленні являється великою скарбницею всіх барв народності, які збагачують не тільки наше уявлення, але і відігра- ють велику роль у розкритті емоційного і артистичного стану спортсменок художньої гімнастики протягом виконання змагальної програми. Визначена динаміка змін показників виконання змагальних програм спортсменками художньої гімнастики у відсотковому співвідношенні по групам свідчить про ефективність запропонованої у навчально-тренувальному процесі методики вдосконалення технічної підготовленості спортсменок художньої гімнастики засобами народно-сценічного танцю.

Конфлікт інтересів. Автори заявляють, що немає конфлікту інтересів, який може сприйматися як такий, що може завдати шкоди неупередженості статті.

Джерела фінансування. Ця стаття не отримала фінансової підтримки від державної, громадської або комерційної організації.

\title{
Список посилань
}

1. Андрєєва Р. І. (2011), Технологія навчання техніки вправ з обручем на основі спеціальної фізичної підготовки юних гімнасток: автореф. дис. ... на здобуття наук. ступеня канд. наук з фіз. виховання та спорту: спец. 24.00.01. Харків, 20 с.

2. Борисенко С. И. (2000), Повышение исполнительского мастерства гимнасток на основе совершенствования хореографической подготовки: автореф. дис. ... канд. пед. наук: спец.: 13.00.04 . СПб., 21 с.

3. Винер И. А., Терехина Р. Н. (2010), «Система, определяющая соотношение сил в художественной гимнастике на мировом уровне», Ученые записки ун-та им. П.Ф. Лесгафта, № 4. Режим доступа: http://cyberleninka.ru/article/n/sistemaopredelyayuschaya-sootnoshenie-sil-v-hudozhestvennoy-gimnastike-na-mirovom-urovne.

4. Гевара Перез Хорхе Энрике (1994), Содержание хореографических элементов в композиции упражнений спортсменок высокой квалификации в художественной гимнастике : автореф. дис. ... канд. пед. наук : спец. 13.00.04 РГАФК. Москва, 23 с.

5. Зайцев $€$., Колесниченко Ю. (2007), Основи народно-сценічного танцю: навч. посіб. для вищ. навч. закл. культури і мистецтв І-ІУ рівнів акредитації, а також для загальноосвітньої школи, позашкільних та професійних навчальних закладів, системи післядипломної педагогічної освіти. Вид. третє. Вінниця : Нова книга, 416 с.

6. Карпенко Л. А. (2007), «Организация многоуровневого функционирования современной художественной гимнастики», Ученые записки, №8(30), С. 46-49.

7. Колногузенко Б. М. (2018), Хореографічна композиція : метод. посіб. з курсу «Мистецтво балетмейстера»; М-во культури України, Харків. держ. акад. культури, Харків. обл. осередок Нац. хореогр. спілки України. Харків : ХДАК, 207 с.

8. Муллагильдина А. Я. (2016), «Совершенствование артистичности у квалифицированных спортсменок в художественной гимнастике», Слобожанський науково-спортивний вісник, № 4(54). С. 79-83. doi:10.15391/ snsv. 4.014

9. Сергієнко Л. П. (2010), Спортивна метрологія: теорія і практичні аспекти. Київ: КНТ, 776 с.

10. Сосина В. Ю. (2009), Хореография в гимнастике: учеб. пособие для студ. Вузов. Киев: Олимп. литература, 135 с.

11. Таранцева О. (2002), «Історичні передумови розвитку національної народно-сценічної хореографії», Рідна школа, № 4. C. 71-73.

12. Шипилина И. А. (2004), Хореография в спорте: учеб. для студ. Ростов-на-Дону : Феникс, 224 с.

13. Фахриева И. А., Кузьменко М. В. (2011), «Пути совершенствования хореографической подготовки спортсменок $12-14$ лет, занимающихся эстетической гимнастикой», Физическая культура: воспитание, образование, тренировка, № 3. С. 62-64.

14. Aerobic gymnastics (2016), Code of Points 2017-2020. Federation Internationale de gymnastique, $203 \mathrm{p}$.

15. Rhythmic gymnastics (2018), Code of Points 2017-2020. Federation Internationale de gymnastique, $82 \mathrm{p}$.

16. Louppe Laurence (1997), Poetique de la danse contemporaine / Laurence Louppe. Paris: Contredanse, $336 \mathrm{p}$.

17. Todorova V. H. (2017), «Peculiarities of Objective Evaluation of Choreographic Preparedness at Different Stages of Long-Term Athletic Performance (Through the Example of Aerobic Gymnastics)», Science and Education, № 2. pp. 63-69.

Стаття надійшла до редакції: 18.01.2021 р.

Опубліковано: 22.02.2021 р.

\begin{abstract}
Аннотация. Петр Кызим, Наталия Батеева. Совершенствование технической подготовленности спортсменок художественной гимнастики средствами народно-сценического танца. Цель: экспериментально обосновать совершенствование технической подготовленности спортсменок художественной гимнастики возраста 10-12 лет средствами народно-сценического танца. Материал и методы: теоретический анализ и обобщение данных специальной научно-методической литературы, педагогическое наблюдение, педагогическое тестирование, педагогический эксперимент, метод экспертных оценок, методы математической статистики. В исследовании приняли участие 14 гимнасток в возрасте 10-12 лет. Разделены на две группы: контрольную группу (КГ) 7 гимнасток и основную группу (ОГ) 7 гимнасток. Результаты: обнаружено, что уровень технической подготовленности более ощутимо вырос у гимнасток основной группы, где в учебно-тренировочном процессе применены средства народно-сценического танца. Выводы: установлено положительное влияние средств народно-сценического танца на динамику уровня технической подготовленности спортсменок по художественной гимнастике. Подтверждением эффективности разработанной методики было статистические изменения у гимнасток основной группы. У гимнасток контрольной группы наблюдалась положительная динамика результатов, но статистически значимых изменений не наблюдалось.
\end{abstract}

Ключевые слова: художественная гимнастика, спортсменки, техническая подготовленность, народно-сценический танец. 


\title{
СЛОБОЖАНСЬКИЙ НАУКОВО-СПОРТИВНИЙ ВІСНИК
}

\begin{abstract}
Petro Kyzim, Nataliya Batieieva. Improving the technical training of rhythmic gymnastics athletes by means of folk-stage dance. Purpose: to experimentally substantiate the improvement of technical readiness of rhythmic gymnastics athletes aged 10-12 years by means of folk-stage dance. Material and methods: theoretical analysis and generalization of data of special scientific and methodical literature, pedagogical observation, pedagogical testing, pedagogical experiment, method of expert assessments, methods of mathematical statistics. The study involved 14 gymnasts aged 10-12 years. Divided into two groups: control group (CG) 7 gymnasts and the main group (OG) 7 gymnasts. Results: it was found that the level of technical training has increased significantly in the athletes of the main group, where in the training process used the means of folk stage dance. Conclusions: the positive influence of folk-stage dance means on the dynamics of the level of technical readiness of female athletes in rhythmic gymnastics has been established. Confirmation of the effectiveness of the developed technique was a statistical change in the gymnasts of the main group. The gymnasts of the control group showed positive dynamics of results, but no statistically significant changes were observed.

Keywords: rhythmic gymnastics, sportswomen, technical readiness, folk-stage dance.
\end{abstract}

\section{References}

1. Andreeva, R. I. (2011), Tehnologiya navchannya tehniki vprav z obruchem na osnovi spetsialnoy fizuhnoy pidgotovki yunyih gimnastok [Technology of learning the technique of exercises with a hoop on the basis of special physical training of young gymnasts]. Extended abstract of candidate's thesis. Harkiv, 20 p. (in Ukr.).

2. Boryisenko, S. I. (2000), Povyishenie ispolnitelskogo masterstva gimnastok na osnovesovershenstvovaniya horeograficheskoy podgotovki [Improving the performance skills of gymnasts based on improving choreographic training]. Extended abstract of candidate's thesis. Sankt-Peterburg, 21 p. (in Russ.).

3. Viner, I. A., Terehina, R. N. (2010), «The system that determines the balance of forces in rhythmic gymnastics at the world level», Uchenyie zapiski un-ta im. Lesgafta №4 - Scientific notes of the un-ta them. P.F. Lesgaft. No. 4. URL: http://cyberleninka.ru/ article/n/sistema-opredelyayuschaya-sootnoshenie-sil-v-hudozhestvennoy-gimnastike-na-mirovom-urovne. (in Russ.).

4. Gevara Perez Horhe Enrike (1994), Soderzhanie horeograficheskih elementov v kompozitsii uprazhneniy sportsmenok vyisokoy kvalifikatsii v hudozhestvennoy gimnastike [The content of choreographic elements in the composition of the exercises of highly qualified athletes in rhythmic gymnastics]. Extended abstract of candidate's thesis. Moskva, 23 p. (in Russ.).

5. Zaytsev, E., Kolisnichenko, Yu. (2007), Osnovyi narodno-stsenichnogo tantsu [Fundamentals of folk stage dance]: navchalnyiy posibnyik, Vinnitsa: Nova knyiga, 416 p. (in Ukr.).

6. Karpenko, L. A. (2007), «Organization of multilevel functioning of modern rhythmic gymnastics», Uchenyie zapiski, №8(30), pp. $46-49$ (in Russ.).

7. Kolnouzenko, B. M. (2018), Horeografichna kompozyitsiya [Choreographic composition]: metodyichnyiy posibnyik, Harkiv: HDAK, 207 p. (in Ukr.).

8. Mullagildena, A. Ya. (2016), «Improving artistry among qualified athletes in rhythmic gymnastics», Slobozhanskiy naukovosportivnyiy vicnyik, № 4(54), pp. 79-83. (in Ukr.).

9. Sergienko, L. P. (2010), Sportyivna metrologiya: teoriya i praktyichni aspektyi [Sports metrology: theory and practical aspects], Kyiiv, 776 p. (in Ukr.).

10. Sosina, V. Yu. (2009), Horeografiya v gimnastike [Choreography in gymnastics]: uchebnoe posobie. Kiev: Olimpiyskaya literature, 135 p. (in Ukr.).

11. Tarantseva, O. (2002), "Historical preconditions for the development of national folk-stage choreography», Ridna shkola native school, №4, pp. 71-73. (in Ukr.).

12. Shipilina, I. A. (2004), Horeografiya v sporte [Choreography in sports]. Rostov-na-donu: Feniks, 224 p. (in Russ.).

13. Fahrieva, I. A., Kuzmenko, M. V. (2011), «Ways of improving the choreographic training of athletes 12-14 years old, engaged in aesthetic gymnastics», Fizicheskaya kultura: vospitanie, obrazovanie, trenirovka, №3, pp. 62-64. (in Russ.).

14. Aerobic gymnastics (2016), Code of Points 2017-2020. Federation Internationale de gymnastique. 203 p. (in Eng.).

15. Rhythmic gymnastics (2018), Code of Points 2017-2020. Federation Internationale de gymnastique, 82 p. (in Eng.).

16. Louppe Laurence (1997), Poetique de la danse contemporaine. Paris: Contredanse, 336, p.1. (in France).

17. Todorova, V. H. (2017), «Peculiarities of Objective Evaluation of Choreographic Preparedness at Different Stages of LongTerm Athletic Performance (Through the Example of Aerobic Gymnastics)», Science and Education. № 2. pp. 63-69. (in Ukr).

Received: 18.01.2021.

Published: 22.02.2021.

\section{Відомості про авторів / Information about the Authors}

Кизім Петро Миколайович: доцент; Харківська державна академія фізичної культури: вул. Клочківська, 99, м. Харків, 61058, Україна.

Кызим Пётр Николаевич: доцент; Харьковская государственная академия физической культуры: ул. Клочковская, 99, г. Харьков, 61058, Украина.

Petro Kyzim: Associat Professor; Kharkov State Academy of Physical Culture: Klochkovskaya 99, Kharkov, 61058,Ukraine.

ORCID.ORG/0000-0001-5094-3988

E-mail: petrkyzim@i.ua

Батєєва Наталія Петрівна: к.фіз.вих., доцент; Київський національний університет культури та мистецтв: вул. Є. Коновальця 36, м. Київ, 01133, Україна.

Батеева Наталия Петровна: к. физ.восп., доцент; Киевский национальный университет культуры и искусств: ул. Е. Коновальця 36, г. Киев, 01133, Украина.

Nataliya Batieieva: PhD (Physical Education and Sport), Associate Professor; Kiev National University of Culture and Arts: E. Konovaitsia, 36, Kiev, 01133, Ukraine.

ORCID.ORG/0000-0001-8214-1592

E-mail: kyzim@i.ua 